\title{
A Comparative Study of Insecurity among Government and Non Government School Teachers
}

\author{
Kiran Vaghela $^{1} *$
}

\section{ABSTRACT}

Aim of the research is to find out the Insecurity among School teachers. So investigator selected two groups one is government school teachers and other is non government school teachers, both groups have 400 persons. In one group has 200 and other one groups has 200 persons. The all subjects were randomly selected. Data were collected from Ahmadabad district. Scale was use for data collection is personal datasheet and Insecurity scale developed by Indian Adaption of Maslow's security insecurity feeling inventory constructed and standardized Tasmeen Nagvi, and data were analysis by "F" test. Result show, There is no significant difference between the Insecurity of government and non government school teachers. There is no significant difference between the Insecurity of male and female and urban and rural area.

\section{Keywords: Insecurity, Government and Non Government School Teachers}

Education leaves a lasting impression on every Human being. Every age bring forth its own value. With the development in technology and corresponding evolution of the objectives of education, the Aims of Education also undergo changes. Education of human child is similar all over the world. System of education Administration is a latest development. Here Systems of education in different countries are examined. The purpose and assimilate good points of education from other countries in order to improve teaching and learning process.

Insecurity feeling is a sign of an indefinite condition of feeling unsafe, threat, and fear. Security being a basic need, as suggested by Maslow, a feeling of insecurity results in retaliation and aggression. According to Maslow \& Hirach, Elisa (1953), huma desires are arranged in ascending hierarchy of needs. As soon as one need is satisfied the next need in the hierarchy is activated. They are safety and security needs belongingness and love needs self-esteem needs and lastly self actualization needs or needs of personal fulfilment. Feeling of helplessness, un-protectedness and inadequacy in the face of manifold anxieties arising from uncertainty regarding one's goals, ideals, abilities and relations to others.

\footnotetext{
${ }^{1}$ Research Scholar, Dept. of Psychology, Sardar Patel University, Vallabh Vidyanagar, Gujarat, India *Responding Author

(C) 2017 Vaghela K; licensee IJIP. This is an Open Access Research distributed under the terms of the Creative Commons Attribution License (www.creativecommons.org/licenses/by/2.0), which permits unrestricted use, distribution, and reproduction in any Medium, provided the original work is properly cited.
} 
Who struggle with insecurity find themselves vulnerable to being led into unhealthy situations; the reason that if one can identify this characteristic in his own life, he must take great strides to seek changes. Who is familiar with these struggles can generally look back in their lives and see the path of this destruction (mild or severe); poor choices in friendships, poor decisions, poor choices of boundaries, poor communications and so on.

In the same way insecurity affects the way a man may see people and things around his it also affects the way he sees himself. He may feel as though he is worthless, even to extreme degree. In his mind nothing about himself is appealing but useless. Oftentimes this will manifest itself in choices such as lack of care by the others. Building a persona of success to mask the fear of being found deficient can be present in the insecure heart.

Insecurity is a feeling of general unease or nervousness that may be triggered by perceiving one to be unloved, inadequate or worthless. Ones adult feels insecure he lacks confidence in their own value and capability, trust in themselves or others, or has fears that a present positive state is temporary and will let them down and cause them loss or distress by 'going wrong' in future. This is not to be confused with humility, which involves recognising one's failings but still maintaining a healthy dose of self-confidence. Insecurity is not an objective evaluation of one's ability but an emotional interpretation, as two people with the same capabilities may have entirely different levels of insecurity.

Insecurity can stem from the individual's immediate environment. People are not born insecure, it is a learned behaviour. From a young age people are told how to be and what to be. Insecurity may cause shyness, paranoia and social withdrawal, or alternatively it may encourage compensatory behaviours such as arrogance, aggression, or bullying a principle enshrined in the phrase 'all bullies are cowards'. Many people suffer a period of insecurity during puberty, which gives rise to a lot of the stereotypical behaviours of adult.

Insecurity has many effects in a person's life. There are several levels of it. It nearly always causes some degree of isolation as a typically insecure person withdraws himself or herself to some extent. The greater insecurity means the higher degree of isolation. Insecurity is often rooted in a person during their childhood years. Like offense and bitterness, it grows in layer fashion, often, becoming an immobilising force that sets a limiting factor in the person's life.

Insecurity robs by degrees - the degree it is entrenched is the degree of power it has in the person's life. In situations such as these, teens may fear humiliation, rejection, social isolations, or another consequence they think they can't handle. Suicide attempts occur under conditions like this because in desperation and confusion, some teens see no other way out.

\section{Aims of the study:}

1) To study of the Insecurity among government and non government school teachers.

2) To study of the Insecurity among male and female.

3) To study of the Insecurity among urban and rural area. 


\section{Hypotheses}

1. There is no difference between Insecurity of government and non government school teachers.

2. There is no difference between Insecurity of male and female.

3. There is no difference between Insecurity of urban and rural areas school teachers.

4. There is no interaction effect of Insecurity on types of school and sex.

5. There is no interaction effect of Insecurity on types of school and types of areas.

6. There is no interaction effect of Insecurity on sex and types of areas.

7. There is no interaction effect of Insecurity on types of school, sex and types of areas.

\section{METHODOLOGY}

\section{Research design:}

This research will be adopted $2 \times 2 \times 2$ factorial design as well as 1 is types of School(Government and Non government), 2 is type of sex (Male and female) 3 is types of area(urban and rural).

\section{$2 \times 2 \times 2$ Factorial Design}

$\mathrm{N}=400$

\begin{tabular}{|l|l|l|l|l|}
\hline & \multicolumn{2}{l|}{$\begin{array}{l}\text { Government School } \\
\text { Teachers (A1) }\end{array}$} & \multicolumn{2}{l|}{ Non government school Teachers (A2) } \\
\cline { 2 - 5 } & Male B1 & Female B2 & Male B1 & Female B2 \\
\hline Urban (C1) & 50 & 50 & 50 & 50 \\
\hline Rural (C2) & 50 & 50 & 50 & 50 \\
\hline
\end{tabular}

\section{Sample:}

In this research study of government and non government school teachers shall be selected from Ahmadabad city and there rural areas. This sample will selected by random sampling method. A total of 400 teachers shall be selected. Out of which 200 would be government school teachers and 200 non government school teachers. Out of which 100 would be male and 100 female. From each of this 50 urban area school teacher and 50 rural areas school teacher would take.

\section{Tools used:}

The following tools were used in the present study:

1) Security - Insecurity feeling scale :

Indian Adaption of Maslow's security insecurity feeling inventory constructed and standardized Tasmeen Nagvi There is 47 sentences in the scale. All at the sentence had a two options "yes" or "no" belong two options can choose one option and marked by symbol $(\sqrt{ })$ in sentences 1 score for yes and 0 score for no. The test retest reliability coefficient is 0.83 . It is standardized on 100 students of higher education. His known has very good Hindi and Gujarati languages and the test retest validity is 0.74 . 
Statistical Analysis:

In this study „fee test was used for statistical analysis.

\section{RESULT AND DISCUSSION}

Insecurity with reference type of school, sex and types of area :

The main objective was to study whether types of school (government and nongovernment), types of sex (male and female), and types of area (urban and rural) differ in Insecurity. In this context, 7 null hypotheses were constructed. For this purpose 2x2x2 factorial design was framed. To examine these null hypothesis statistical techniques of two ways ANOVA was used. The results obtained are presented in table 1, 2, and 3.

Table no 1, Means and SDs of Insecurity with reference type of school, sex and types of $\operatorname{area}(N=400)$

\begin{tabular}{|c|c|c|c|c|}
\hline \multicolumn{3}{|c|}{ Independent variable } & Urban area & Rural area \\
\hline \multirow{6}{*}{$\begin{array}{l}\text { Government } \\
\text { school }\end{array}$} & \multirow[b]{3}{*}{ Male } & Mean & 24.90 & 25.32 \\
\hline & & SD & 3.46 & 2.62 \\
\hline & & $\mathrm{N}$ & 50 & 50 \\
\hline & \multirow[b]{3}{*}{ Female } & Mean & 24.76 & 24.62 \\
\hline & & SD & 3.85 & 3.56 \\
\hline & & $\mathrm{N}$ & 50 & 50 \\
\hline \multirow{6}{*}{$\begin{array}{l}\text { Non } \\
\text { government } \\
\text { school }\end{array}$} & \multirow[b]{3}{*}{ Male } & Mean & 27.56 & 25.87 \\
\hline & & SD & 17.20 & 13.42 \\
\hline & & $\mathrm{N}$ & 50 & 50 \\
\hline & \multirow[b]{3}{*}{ Female } & Mean & 25.02 & 27.35 \\
\hline & & SD & 4.01 & 4.25 \\
\hline & & $\mathrm{N}$ & 50 & 50 \\
\hline
\end{tabular}

Table no.2, ANOVA summary of Insecurity with reference type of school, sex and types of area. $(N=400)$

\begin{tabular}{|l|l|l|l|l|l|}
\hline Source of variance & $\begin{array}{l}\text { Sum } \\
\text { of } \\
\text { squares }\end{array}$ & Df & $\begin{array}{l}\text { Mean } \\
\text { Sum of } \\
\text { squares }\end{array}$ & F & $\begin{array}{l}\text { Sign. } \\
\text { Level }\end{array}$ \\
\hline Type of school & 241.04 & 1 & 241.04 & 4.96 & 0.01 \\
\hline Sex & 22.67 & 1 & 22.67 & 0.69 & NS \\
\hline Types of area & 5.41 & 1 & 5.41 & 1.11 & NS \\
\hline Type of school x sex & 0.31 & 1 & 0.31 & 0.06 & NS \\
\hline Type of school x Types of area & 0.85 & 1 & 0.85 & 0.18 & NS \\
\hline sex $x$ Types of area & 74.61 & 1 & 74.61 & 1.53 & NS \\
\hline $\begin{array}{l}\text { Type of school x sex } x \text { Types of } \\
\text { area }\end{array}$ & 130.82 & 1 & 130.82 & 2.69 & NS \\
\hline SSW (Error) & 19028.49 & 392 & 48.54 & & \\
\hline \multicolumn{2}{|l|}{} & & & \\
\hline SST & 283292.000 & 400 & & & \\
\hline P $>0.01, * * P>0.05, N S=$ Not Significant & & & \\
\hline
\end{tabular}


Table no.3, Difference between mean score of Insecurity with reference to type of school, gender and types of area. $(N=400)$

\begin{tabular}{|l|c|l|l|}
\hline Independent variable & & & $\begin{array}{l}\text { Difference } \\
\text { between mean }\end{array}$ \\
\hline Government school(A1) & $\mathrm{N}$ & Mean (M) & 2.62(A1 x A2) \\
\hline Non government School(A2) & 200 & 24.90 & \\
\hline Male(B1) & 200 & 26.46 & $0.46(\mathrm{~B} 1 \times \mathrm{B} 2)$ \\
\hline Female(B2) & 200 & 25.91 & $0.24(\mathrm{C} 1 \mathrm{xC} 2)$ \\
\hline Urban (C1) & 200 & 25.44 & \\
\hline Rural(C2) & 200 & 25.56 & \\
\hline
\end{tabular}

Insecurity with reference to type of school:-

HO 1 There is no different between Insecurity of government and non government school teachers.

When $f$ test was applied to check the impact of Insecurity on type of school, significant $f$ value was found. The $\mathrm{f}$ value (table no 2 ) is 4.96 which are statistically significant. Table no.4.9 reveals that the mean scores of Insecurity of Government and Non government school are 24.90 and 26.46 respectively and the difference between two is 2.62 which is very high and not negligible. Hence the null hypothesis 1 was rejected and it was concluded that there was significant impact and the of Insecurity on Government and non government school teacher.

\section{Insecurity with reference to gender :-}

HO 2 There is no difference between Insecurity of male and female.

When $\mathrm{f}$ test was applied to check the impact of Insecurity on gender, significant $\mathrm{f}$ value was found. The $f$ value (table no.2) is 0.46 which are statistically not significant Table no.4.9 reveals that the mean score of Insecurity of male and female are 25.91 and 25.44 respectively and the difference between two is 0.46 which is very low and negligible. Hence the null hypothesis 2 was maintained and it was concluding that there not significant impact of Insecurity on male and female.

\section{Insecurity with reference to types of area:-}

HO 3 There is no difference between Insecurity of urban and rural areas school teachers.

When $\mathrm{f}$ test was applied to check the impact of Insecurity on types of area, significant $\mathrm{f}$ value was found. The $\mathrm{f}$ value (table no 2) is 0.11 which is statistically not significant. Table no 4.9 reveals that the mean scores of Insecurity of area are 25.56 and 25.80 respectively and the difference between two is 0.24 , which is very low and negligible. Hence the null hypothesis 3 was maintained and it was concluded that there was not any significant impact of Insecurity on urban and rural area. 
Insecurity with reference to interaction effect of type of school and gender HO 4 There is no interaction effect of Insecurity on types of school and gender.

When $\mathrm{f}$ test was applied to check the interaction effect of Insecurity on type of school and sex, significant interaction effect was found. The $f$ value (table no 2) is 0.06 which are statistically not significant. Hence the null hypothesis 4 was maintained and it was conclude that there was not significant interaction effect of Insecurity on type of school and gender.

Insecurity with reference to interaction effect of type of school and types of area HO 5 There is no interaction effect of Insecurity on types of school and types of areas. When $\mathrm{f}$ test was applied to check the interaction effect of Insecurity on types of school and types of area, significant interaction effect was found. The f value (table no 2) is 0.01 which is statistically not significant. Hence the null hypothesis 5 was maintained and it was conclude that there was not significant interaction effect of Insecurity on type of school and types of area.

Insecurity with reference to interaction effect of gender and types of area. HO 6 There is no interaction effect of Insecurity on gender and types of areas.

When $\mathrm{f}$ test was applied to check the interaction effect of Insecurity on gender and types of area, significant $f$ value was found. The $f$ value (table no 2 ) is 1.53 which are statistically not significant. Hence the null hypothesis 6 was maintained and it was concluded that there was not significant interaction effect of sex and types of area.

Insecurity with reference to interaction effect of types of school, gender and types of area

HO 7 There is no interaction effect of Insecurity on types of school, gender and types of areas.

When $\mathrm{f}$ test was applied to check the interaction effect of type of school, gender and types of area, significant $f$ value was found. The $f$ value (table no.2) is 2.69 which are statistically no significant. Hence the null hypothesis 7 was maintained and it was concluded that there was no significant interaction effect of type of school, gender and types of area.

\section{CONCLUSION}

There is significant difference between Insecurity of government and non government school teachers.

1. There is no significant difference between Insecurity of male and female.

2. There is no significant difference between Insecurity of urban and rural areas school teachers.

3. There is no significant interaction effect of Insecurity on types of school and gender.

4. There is no significant interaction effect of Insecurity on types of school and types of areas.

5. There is no significant interaction effect of Insecurity on gender and types of areas.

6. There is no significant interaction effect of Insecurity on types of school, gender and types of areas. 


\section{REFERENCES}

Alam Q.G. and Shrivastava (1980). Punctuality as a function of inferiority and insecurity feelings. Perspective in psychological Researcher: (3) 37-39.

Anderson, C. J., \& Pontusson, J. (2007). Workers, worries and welfare states: Social protection and job insecurity in 15 OECD countries. European Journal of Political Research, 46(2), 211-235

De Witte, H. (1999). Job insecurity and psychological well-being: Review of the literature and exploration of some unresolved issues. European Journal of Work and Organizational Psychology, 8(2), 155-177.

Erlinghagen, M. (2008). Self-perceived job insecurity and social context: A multi-level analysis of 17 European countries. European Sociological Review, 24(2), 183197.

Maslow, A.H., and Hirach, Elisa (1953). Test of security-insecurity. The journal of General Psychology, 1953.

Saha G. B. and Gupta, S. (1980). A study of adjustment and insecurity feeling among the adolescents of two type of family. Paper presented.

Sverke, M., Hellgren, J., \& Näswall, K. (2002). No security: A meta-analysis and review of job insecurity and its consequences. Journal of Occupational Health Psychology, 7(3), 242-264.

How to cite this article: Vaghela K (2017). A Comparative Study of Insecurity among

Government and Non Government School Teachers. International Journal of Indian Psychology, Vol. 5, (1), DIP: 18.01.116/20170501, DOI: 10.25215/0501.116 